\title{
AUTOMATED CLASSIFICATION OF LANDFORMS WITH GIS SUPPORT
}

https://doi.org/10.4215/rm2020.e19012

\author{
Luís Eduardo de Souza Robaina $\mathrm{a}^{*}$ - Romário Trentin $\mathrm{b}$
}

(a) Dr. in Geosciences. Professor at the Federal University of Santa Maria, Santa Maria (RS), Brazil.

ORCID: http://orcid.org/0000-0002-2390-6417. LATTES: http://lattes.cnpq.br/6075564636607843.

(b) Dr. in Geography. Professor at the Federal University of Santa Maria, Santa Maria (RS), Brazil.

ORCID: http://orcid.org/0000-0002-0615-2801. LATTES: http://lattes.cnpq.br/2287005710639329.

\author{
Article history: \\ Received 21 January, 2019 \\ Accepted 09 April, 2020 \\ Publisher 15 May, 2020
}

\section{(*) CORRESPONDING AUTHOR}

Address: UFSM, Avenida Roraima, 1000, Prédio 17, sala 1113c, CEP: 97105-900, Santa Maria (RS), Brazil. Tel: (+55 55) 3220.8639.

E-mail: romario.trentin@gmail.com

\section{Abstract}

Relief classification methodologies seek to define the parameters that determine those parts of the terrestrial surface that present homogeneous forms and elements. The rapid development of geotechnology has increasingly provided tools and methodologies that assist in studies related to relief. The present work proposes a methodology to classify the relief in three taxonomic levels, using automated processing in a GIS environment. This procedure was applied in a case study of the Santa Maria River basin, in the west of Rio Grande do Sul State, Brazil. The digital data processing employed was the Geographic Information System ArcGIS ${ }^{\circ}$ and the data from the SRTM 3 arc-second radar (90 meters) was the basis for the Digital Elevation Model. The processing for the first taxon used the amplitude and slope data to define four forms of relief: flat areas, slightly undulating hills, undulating hills, and hills with buttes and larger hills. In the second taxonomic level, ten relief elements were identified: flat, peak, ridge, shoulder, spur, slope, hollow, footslope, valley, and pit. In the third taxonomic level, the slope forms were characterized into eight units using the slope, profile, and curvature plane parameters. It was possible to detect the three proposed levels, the relief forms, relief elements, and slope forms. GIS processing offers a fast and precise definition of the relief forms and elements, and the slope forms, as well as the relationship between the three taxonomic levels.

Keywords: Relief; Geomorphons, Geomorphometry; Hydrographic Basin.

\section{Resumo / Resumen}

\section{CLASSIFICAÇÃo AUTOMATIZADA DE RELEVO COM APOIO DE SIG}

As metodologias de classificação do relevo, buscam definir parâmetros que determinam porções da superfície que apresentem características homogêneas quanto as formas e elementos. O desenvolvimento acelerado das geotecnologias, possibilita cada vez mais o uso de ferramentas e metodologias que permitem o auxílio de estudos relacionados ao relevo. O presente trabalho possui como objetivo a proposição metodologia da classificação do relevo em três níveis taxonômicos, utilizando processamento automatizados em ambiente SIG. A presente proposição foi aplicada em um estudo de caso na bacia hidrográfica do rio Santa Maria, oeste do Rio Grande do Sul. Para o processamento digital dos dados utilizou-se

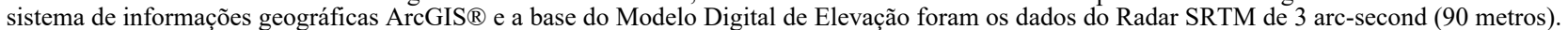
O processamento para o primeiro táxon foi utilizado através dos dados de amplitude e declividade para definir quatro formas de relevo, sendo elas: áreas planas, colinas levemente onduladas, colinas onduladas e associação de morros e morrotes. No segundo nível taxonômico definiu-se dez elementos de relevo denominados: áreas planas, pico, crista, ressalto, crista secundária, encosta, escavado, base da encosta, vale e fosso. No terceiro nível taxonômico foram definidas as formas das vertentes em oito unidades através dos parâmetros de declividade, perfil e plano de curvatura. O processamento em SIG permitiu de forma rápida e precisa estabelecer as formas de relevo, os elementos de relevo e as formas das vertentes, além da relação entre os três níveis taxonômicos.

Palavras-chave: Relevo; Geoformas, Geomorfometria; Bacia Hidrográfica.

\section{CLASSIFICATION AUTOMATISÉE DES RELIEF AVEC LE SOUTIEN DE SIG}

Les méthodologies de classification des reliefs cherchent à définir des paramètres qui déterminent les portions de la surface qui présentent des caractéristiques homogènes en termes de formes et d'éléments. Le développement accéléré des géotechnologies, permet de plus en plus l'utilisation d'outils et de méthodologies qui permettent l'aide d'études liées au relief. Ce travail vise à proposer une méthodologie de classification des reliefs à trois niveaux en utilisant un traitement automatisé dans un environnement SIG. La présente proposition a été appliquée dans une étude de cas dans le bassin hydrographique de la rivière Santa Maria, à l'ouest de Rio Grande do Sul. Pour le traitement numérique des données a été utilisé système d'information géographiqueet ArcGIS $®$ et la base du modèle numérique d'élévation était les données du radar SRTM 3 secondes d'arc (90 mètres). Le traitement de la première catégorie d'analyse a été utilisé à travers les données d'amplitude et de pente pour définir quatre formes de relief, à savoir: les zones plates, les collines légèrement vallonnées, les collines vallonnées et l'association des buttes et petites buttes. Au deuxième niveau d'analyse, dix éléments de relief ont été définis: zones planes, pic, crête, épaule, arête secondaire, pente, excavé, base de la pente, vallée et fossé. Au troisième niveau sont définies les formes des pentes en huit unités à travers les paramètres le profil et plan. Le traitement SIG a permis d'établir rapidement et avec précision les formes en relief, les éléments en relief et les formes des pentes, en plus de la relation entre les trois niveaux d'analyse.

Palabras-clave: Relief; Géoformes, Géomorphométrie; Bassin Versant. 


\section{INTRODUCTION}

Landforms are defined by the spatial arrangement of homogeneous surfaces resulting from the action of tectonic forces that provoke uplifts and relegation, and agents of the terrestrial surface that act on rocky materials, decomposing and disaggregating them over time to develop different features and forms. According to Shary (1995), most landform classifications are implicitly or explicitly based on how the gravitational field interacts with the earth's surface to model or modify superficial shapes.

In Brazil, Ross (1992) has made an important contribution to landform analysis, based on Demek's proposed taxonomic classification (1967), recommending the division of the relief into six different taxa. Nowadays, the development of geoprocessing methods and GIS means the terrestrial surface can be represented through digital models (DEM), which allow the topographic analysis of a zone of interest, as well as the automated calculation of a series of related variables. The DEM parameters are representative descriptors of quantitative relief measurements using equations applied to numeric models of altimetric representation (MUÑOZ, 2009).

Wood's (1996, apud SENA-SOUZA et al., 2015) method considers a specific combination of longitudinal/transversal and minimum/maximum curvature pairs depending on the slope of the region to be classified and identifies six Terrain Forms (TFs): Plane, Channel, Ridge, Saddle, Peak, and Pit. In Brazil, automated landform identification was developed for Paraná State (SILVEIRA, SILVEIRA, 2015), and the central region of the Serra do Mar Paranaense (SILVEIRA, SILVEIRA, 2016), which were defined from the automated crossing of slope declivity and height.

Regarding these natural features, Schmidt and Hewitt (2004) developed a procedure that obtains different elements using the landscape's position as a criterion, dividing it into flat areas and areas dissected from the tangential, vertical, minimum, and maximum curvature. Trentin et al. (2016) and Silveira et al. (2017) use the Topographic Position Index (TPI) to classify landform elements. Jasiewicz and Stepinski (2013) established a classification of these features (the ten most common classes) called geomorphons using computer vision tools, thereby replacing the combination of extractable DEM variables. This proposal was applied by Robaina et al. (2016) in Rio Grande do Sul and Silveira (2018) in Paraná to define the distribution and relationship between landform elements in geomorphological compartments.

The slopes' characteristics were analyzed using three morphometric variables: declivity, profile shape, and plant, according to works by Iwahashi and Pike (2007), Silveira et al. (2014), Trentin et al. (2015, 2016), Gomes et al. (2016), and Robaina et al. (2016).

Landforms are defined as "any physical characteristic of the Earth's Surface with a recognizable shape" (BATES AND JACKSON, 2005). In geomorphometry, another definition is "a land unit created by natural processes in such a way that it can be recognized and described in terms of typical attributes wherever it occurs" (LOBECK, 1939; WEAVER, 1965; HAMMOND, 1965; LEIGHTY, 2001). In Geography, recurring terrain forms compose terrestrial landscape systems (ZINCK and VALENZUELA, 1990; BRABYN, 1997). According to Dikau et al. (1995), types of relief can also be defined as groupings of landform associations and relief patterns (SPEIGHT, 1974). Examples of landforms include plains, hills, mountains, and valleys, which can be observed on various scales.

A landform element is a hierarchical subcomponent of a landform at the level immediately below it. Landform elements can be conceptualized as consisting of parts of a relatively homogeneous type of relief form in relation to the shape (curvature of the profile and plane), inclination (gradient), orientation or exposure (aspect or solar radiation), humidity regime and the relative position of the relief (for example, top, middle or bottom). Dikau (1989) differentiates between shape elements with a homogeneous curvature from the plane and facet's profiles and shapes that have a homogeneous gradient, aspect, and curvature.

Shary (1995) and Shary et al. (2005) proposed an objective, local and specific classification of the scale and elementary characteristics of landforms, based entirely on the signs of curvature. It can be argued that any element of the landform that can be subdivided into smaller and more homogeneous entities is not technically an elementary form.

This work aims to present a three-level automated landscape classification, using a Digital Elevation Model from the Shuttle Radar Topography Mission (SRTM), in a GIS environment. The 
combination of topographic parameters defined four landforms represented by flat areas, hills, buttes, and larger hills. The landform elements are determined by ridges, slopes, valleys, etc.; the slope forms are based on declivity, plane, and profile.

\section{STUDY AREA}

The Santa Maria River Basin is located Southwest of Rio Grande do Sul, between the geographic coordinates $29^{\circ} 47^{\prime}$ to $31^{\circ} 36^{\prime} \mathrm{S}$ and $54^{\circ} 00^{\prime}$ to $55^{\circ} 32^{\prime} \mathrm{W}$. It has an area of $15,609.11 \mathrm{~km}^{2}$, covering municipalities such as Bagé, Dom Pedrito, Rosário do Sul, Santana do Livramento, and São Gabriel, with an estimated population of 220,296 inhabitants (FIGURE 01).

The subtropical climate is influenced by polar systems for $45-48 \%$ days per year, the relief, and its continentality. In this environment, there are between 6 to 12 days of precipitation per month with an average volume of $115-155 \mathrm{~mm}$. The average temperature of the coldest month varies between $11-14^{\circ} \mathrm{C}$ and the warmest month between $23-26^{\circ} \mathrm{C}$ (ROSSATO, 2011). The source of the Santa Maria River is to the northeast of the municipality of Dom Pedrito and it flows into the Ibicuí river. The main tributaries are the Upamaroti, Ponche Verde, Santo Antonio, Jaguari-Taquarembó, Cacequi, Ibicuí da Faxina, and Ibicuí da Cruz rivers, and the Saicã and the Ibicuí da Armada streams.

The Santa Maria River Basin is part of the morphostructural region (RADAM, 1986) of the Complex Basement, approximately 10\% of its total area occupies the extreme SE portion, whilst the rest is in the region of Basins and sedimentary deposits, formed by rocks and sediments in different depositional environments and by the volcanic Plateau.

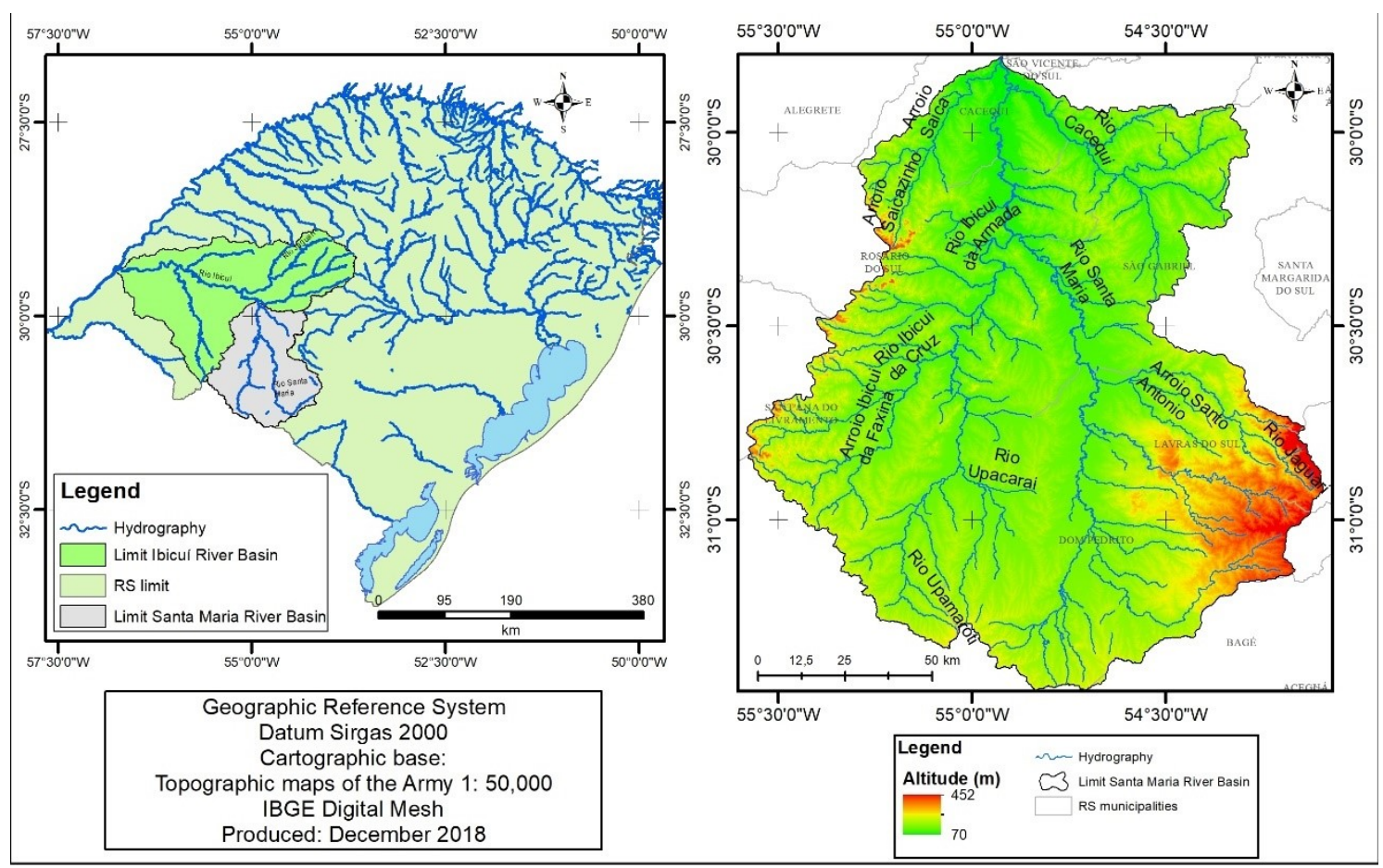

Figure 01 - Map of the location of the Santa Maria River Basin. Source: authors

\section{METHODOLOGY}

The cartographic data used to define the limits of the area of interest of the research were taken from the continuous vector base for Rio Grande do Sul - scale 1: 50,000 (HASENACK AND WEBER, 2010). The analysis of the parameters related to the hydrographic network and the Digital Elevation Model from the Shuttle Radar Topography Mission (SRTM) (KRETSCH, 2000) were provided by the United States Geological Survey (US GEOLOGICAL SURVEY, 2016), with a spatial resolution of 3 
arc-second (90 meters). The processing and the database were organized and managed with ArcGIS $10.3{ }^{\circledR}$, using spatial analysis and three-dimensional analysis tools.

The original version of the DEM of the SRTM 1 Arc-Second, as well as the reprocessed data with NASADEM error correction, were available for the resolution of the MDE of the study area. The NASADEM (USGS, 2020) extends the legacy of the Shuttle Radar Topography Mission (SRTM) by improving the accuracy of heights in the digital elevation model (DEM) and data coverage. It also provides additional data products related to the SRTM's radar, upgrading the reprocessing of the original SRTM radar signal data and telemetry data with updated algorithms and auxiliary data unavailable at the time of the original SRTM processing. However, when the products were processed significant anomalies were found in areas with slopes below $2 \%$. In the study area, flood plains occupy the most extensive sections of the hydrographic basin, thus, the SRTM 3 Arc-Second version 3 data was selected as it had no anomalies and was better suited to the proposed landform representation.

In the present study, the landforms are the first level of analysis that define the general units using the Digital Elevation Model. These forms follow a proposal adapted from the Instituto de Pesquisa Tecnólogicas (IPT, 1981), which uses the altimetric range and declivity of the terrain (TABLE 1).

\begin{tabular}{c|c|c}
\hline Amplitude Altimetric & Declivity & Relief forms \\
\hline \multirow{2}{*}{$<100$ meters } & $<2 \%$ & Flat Areas \\
\cline { 2 - 3 } & $2-5 \%$ & Slightly undulating hills \\
\cline { 2 - 3 } & 5 to $15 \%$ & Undulating hills \\
\cline { 2 - 3 } & $>15 \%$ & Buttes \\
\hline$>100$ meters & $>15 \%$ & Larger hills \\
\hline
\end{tabular}

Table 1 - Classification of the landforms adapted from IPT (1981).

The GIS spatial analysis tools generate the declivity as percentages producing a map with four classes: less than $2 \%$ representing the flat areas, 2 to $5 \%$ representing the slightly undulating areas, 5 to $15 \%$ representing the undulating areas, and the class over $15 \%$ representing profoundly undulating areas.

The slope height is calculated by the GIS focal statistic tool that defines the amplitude gradient by analyzing the maximum and minimum difference in altitude within a mobile window whose size and shape are selected by the user. A circular moving window with a 2-pixel radius was used, as shown in Figure 02 .

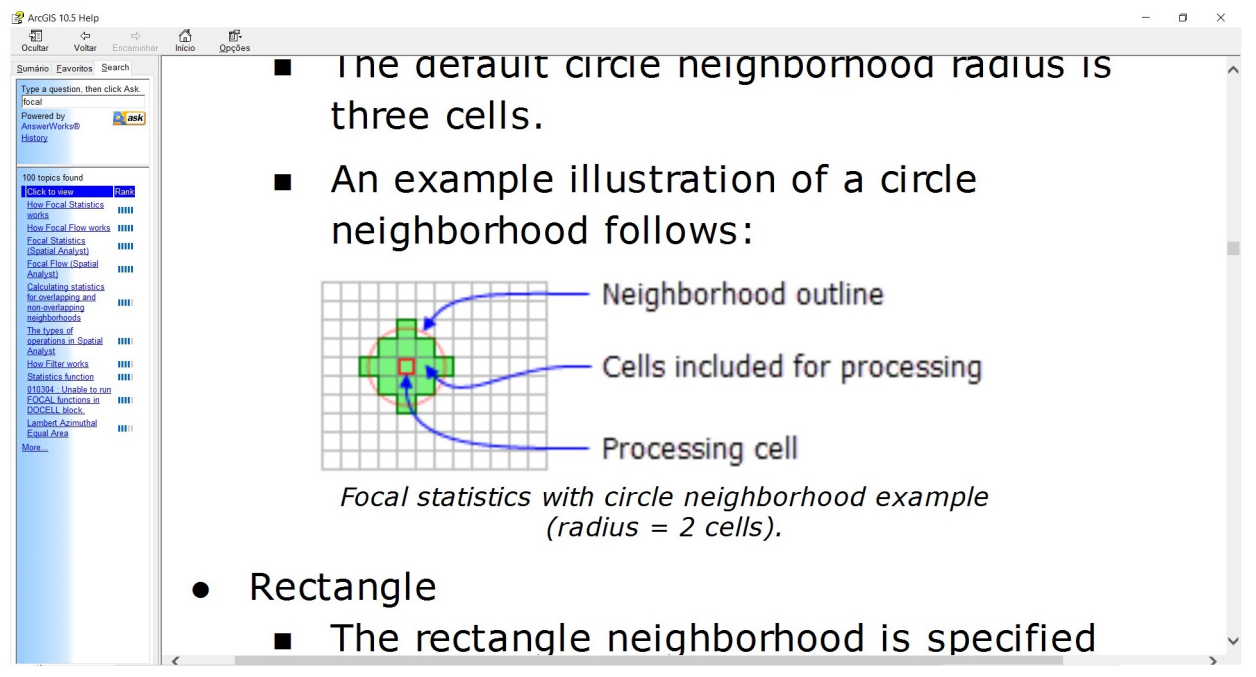

Figure 02 - Circular mobile window of 2 pixels used in the statistical analysis. Source: ArcGIS Help (ESRI, 2018) 
Once the amplitude gradient had been defined, the amplitude variation threshold was established in the analysis circle by examining the topographic profiles in the study area. This determined the variation of the altimetric amplitude under analysis to determine the general amplitude above and below 100 meters.

After the two base layers of declivity and amplitude had been defined, they were spatially crossed in the GIS to classify the landform units.

Jasiewicz and Stepinski's (2013) approach was applied to determine the relief elements, which were characterized as the difference of the topographic height, distance, and the angle of direction of the neighboring points to the central cell (zenith and nadir angles). The elevation angle is the angle between the horizontal plane and the line connecting the central cell with a point in the profile. At a negative elevation angle, the point on the profile is lower than the center. For each profile, the elevation angle "DSL" is calculated, with "D" and "L" demonstrating the direction (D) and distance (L) dependence.

To perform the DEM processing and generate the geomorphons, the online application used was available at the electronic address . The application code is also available for download at and can be implemented in the SAGA GIS environment. The application requires a set of raster data and two scalar values as parameters. The input file for the scan was a DEM and the two parameters are lookup "L" (distance in meters or cell units) and threshold (leveling in degrees). For the free parameters, an "L" value equal to 20 pixels (1800 meters) and degrees " $t$ " equal to $2^{\circ}$ were applied, as this offered the best representation of the landform elements in the study area.

The slopes forms were classified according to their declivity and their curvature in the plane and profile based on the work of Hugget (1975). The DEM information in this research was obtained through the Horn polynomial (1981) and was separated into two classes with 5\% limits.

The plane of the slope curvature corresponds to the variation of the arching gradient of the orthogonal direction (curvature of the surface perpendicular to the direction of the slope) and refers to the divergent/convergent character of the terrain. The curvature profile is the gradient's rate of variation (the curvature of the surface in the direction of the slope) and is related to the convexity/concaveness and is decisive in the acceleration or deceleration of the runoff. Both were obtained from the DEM, using Zevenbergen and Thorne's (1987) polynomial.

The information was cross-referenced using the decision tree presented in the flowchart in Figure 03. In total, eight slopes forms were identified.

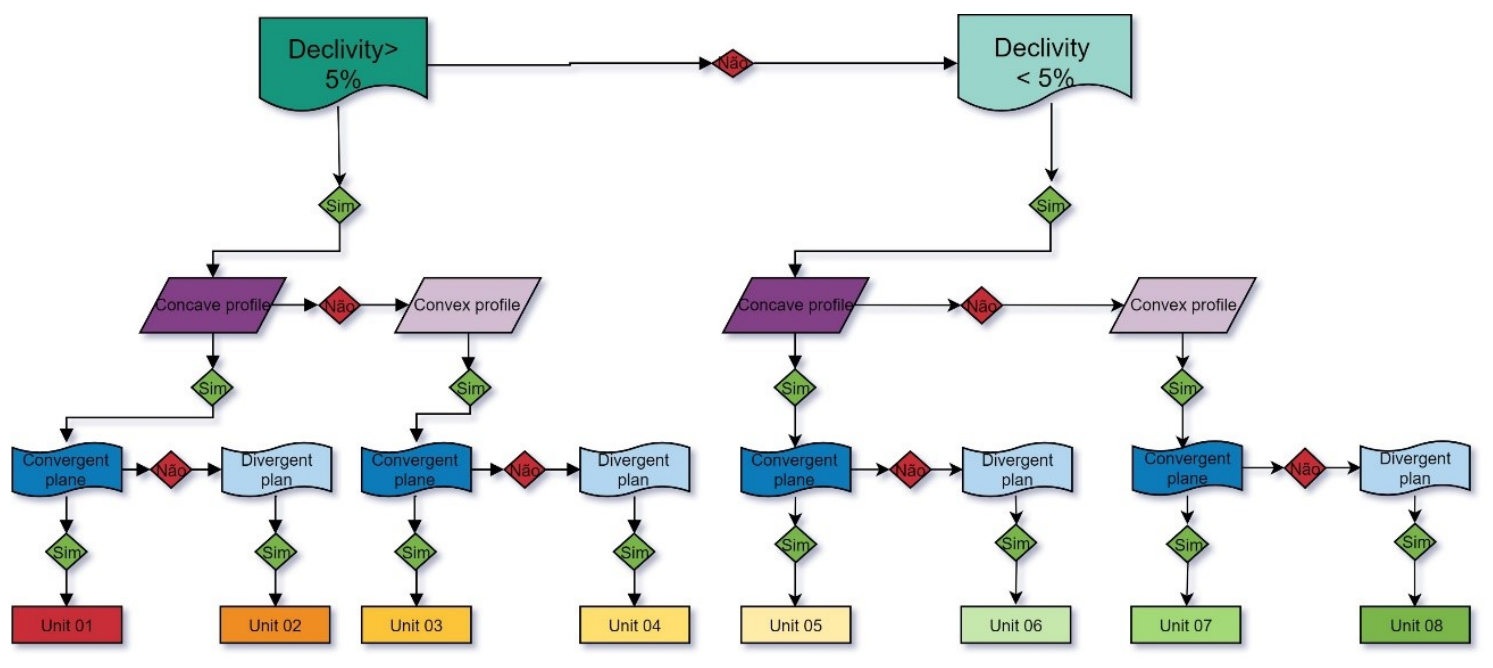

Figure 03 - Decision tree for slope classification. Source: authors

\section{CLASSIFICATION OF LANDFORMS UNITS}

The results below show how the application of specific methodologies outlined above established 
a classification of the landforms in the Santa Maria River basin at different levels.

The study of the topographic height and slope declivity in the basin of the Santa Maria River led to the characterization of four general landforms: flat areas, slightly undulating hills; undulating hills, hills associated with buttes, and larger hills (Figure 04 and Figure 05).

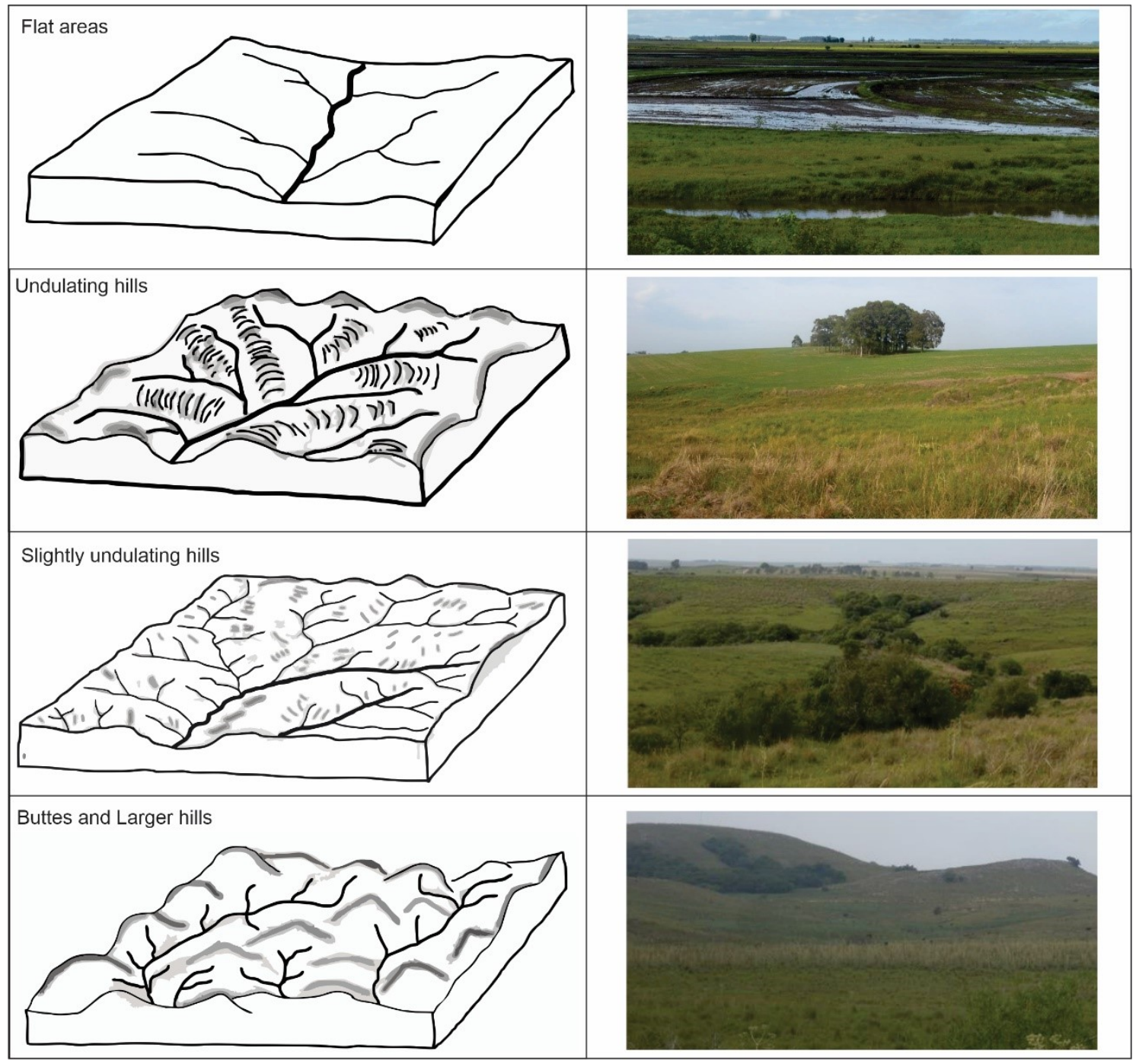

Figure 04 - Schematic representation of the relief forms present in the Santa Maria River Basin. Source: authors

The space occupied by the flat landforms and their percentage of the basin are indicated in Table 02. The flat areas have a declivity below $2 \%$ and are found along the broad river floodplains characterized by accumulation processes. They occupy an area of $4374,46 \mathrm{~km}^{2}$, representing approximately $28 \%$ of the total area of the basin.

\begin{tabular}{|c|c|c|}
\hline Class & Areas $\left(\mathbf{k m}^{2}\right)$ & Percentage \\
\hline Flat Areas & $4,374.46$ & 27.79 \\
\hline Slightly undulating hills & $7,786.94$ & 49.47 \\
\hline Undulating hills & $3,428.43$ & 21.78 \\
\hline Buttes and Larger Hills & 150.57 & 0.96 \\
\hline
\end{tabular}

Table 02 - Quantitative data of relief units of the Santa Maria River basin.

The basin's predominant landforms are the gently undulating hills occupying $49.5 \%$ of the total 
basin. They have amplitudes between $20 \mathrm{~m}$ and $40 \mathrm{~m}$ and a declivity between $2 \%$ and $5 \%$. They result from planing processes and occur throughout the basin, especially over sedimentary rocks in the central portion marine environments of the Paraná Basin.

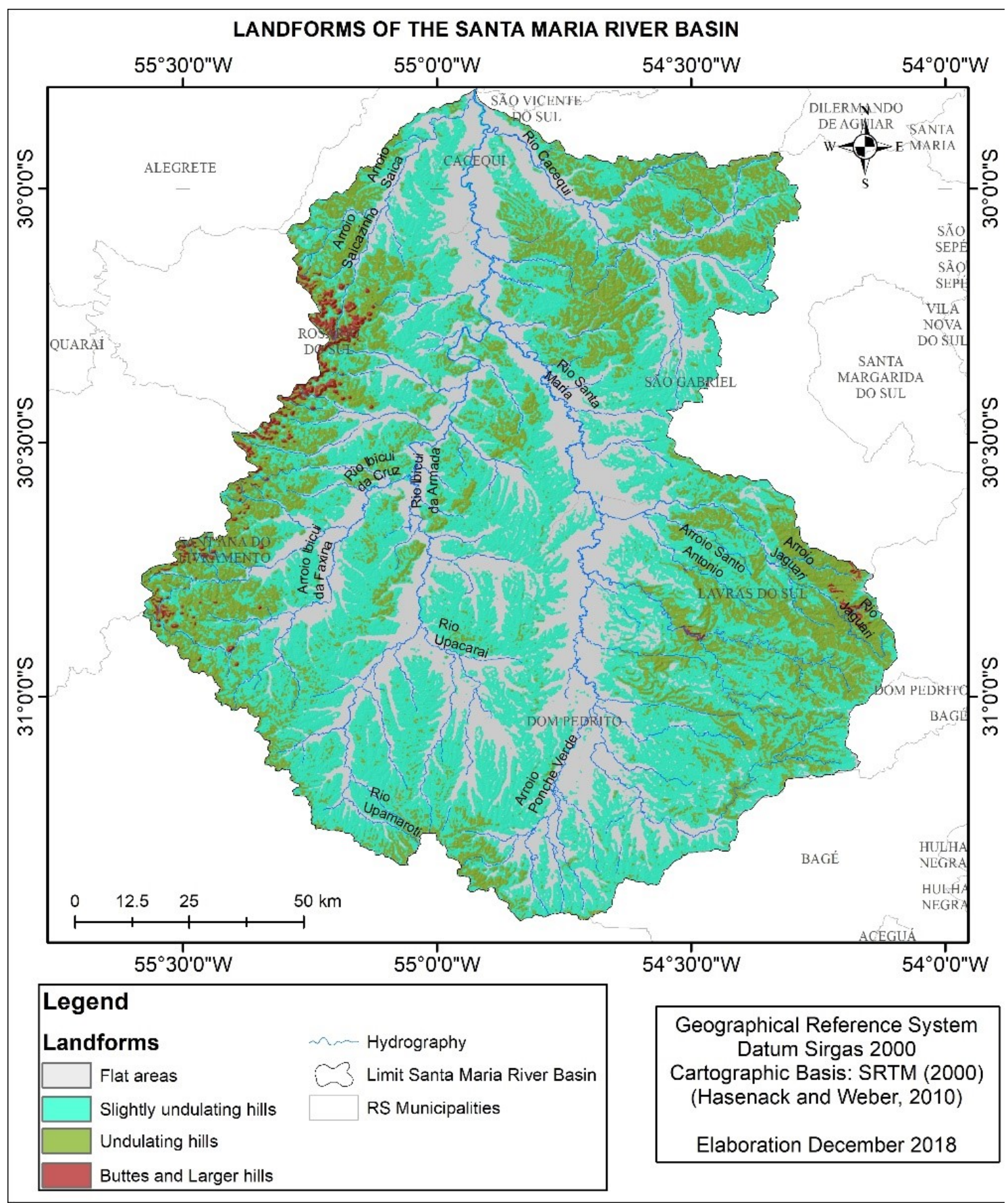

Figure 05 - Spatial distribution of landforms in the Santa Maria River basin. Source: authors

The undulating hills, defined by amplitudes between $40 \mathrm{~m}$ and $60 \mathrm{~m}$ and a declivity between $5 \%$ and $15 \%$, make up $21.78 \%$ of the basin, covering an area of $3,428.43 \mathrm{~km}^{2}$. They are predominantly found in the Cacequi River basin, a tributary of the right bank of the Santa Maria River. It represents a dissection surface on a sequence of eolic continental sedimentary rocks (Lavina 1992, Faccini 2000), which are fine reddish, friable, round-grained sandstones. The landscape of undulating hills is also associated with the Jaguari-Taquarembó river basin, over crystalline rocks.

The belt of larger hills and buttes are associated with the undulating hills with an N150E direction 
in the Western part of the basin, called Serra do Caverá. The hills and the base of the buttes are composed of beige and whitish sandstones, with a coarse medium-grained, sometimes fine, clay matrix, comprised mainly of quartz and subordinated by feldspars. These are interspersed with centimeter packs of pelitic and fine sandstones with ascending ripples (Scherer et al., 2006). The larger hills and buttes are supported by a layer of volcanic rock at the top of varying thickness.

There is also a smaller area of larger hills and buttes landforms in the Eastern portion of the basin, associated with granites and gneisses rocks in the sub-basin of the Jaguari-Taquarembó river, occupying $0.96 \%$ of the total area of the hydrographic basin.

\section{IDENTIFICATION OF THE LANDFORM ELEMENTS}

The automated geomorphometric classification defined ten landforms elements in the basin of the Santa Maria River (Figure 06), namely, Flat, Peak, Ridge, Shoulder, Spur, Slope, Pit, Valley, Footslope and Hollow.

The percentage and area occupied by these different elements are presented in table 03 . The Flat elements predominate in the basin, with more than $55 \%$ of the total.

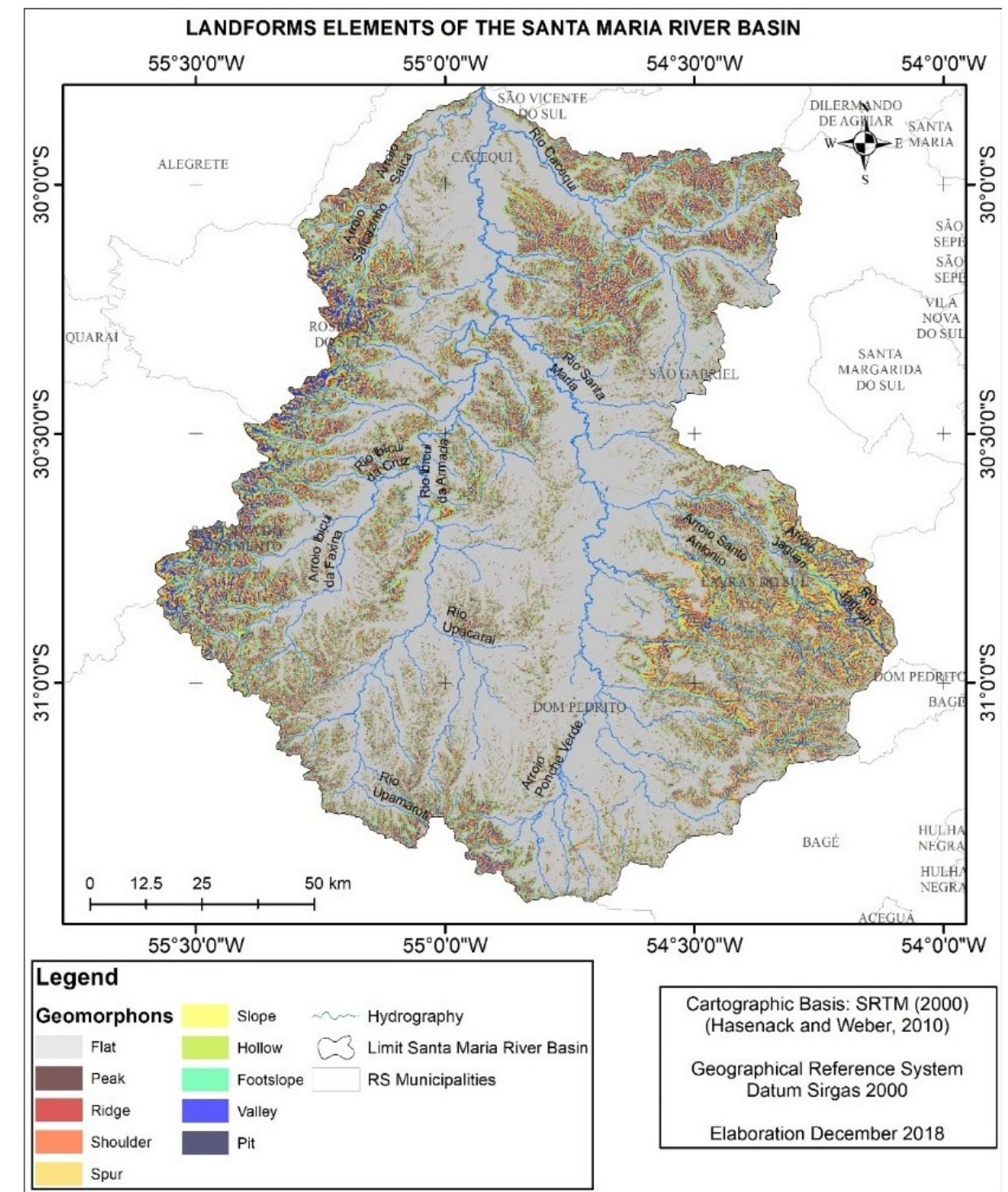

Figure 6 - Spatial distribution of the landform elements in the catchment area of the Santa Maria River. Source: authors. 


\begin{tabular}{l|r|r|r}
\hline \multicolumn{1}{c|}{ Classes } & \multicolumn{1}{c|}{ Area $\mathbf{~ k m}^{2}$} & \multicolumn{1}{c}{ Percentage } & Representation \\
\hline Flat & $8,723.26$ & 55.42 & \\
\hline Peak & 54.14 & 0.34 & \\
\hline Ridge & 881.25 & 5.60 & \\
\hline Shoulder & $1,581.78$ & 10.05 & \\
\hline Spur & 400.35 & 2.54 & \\
\hline Slope & $1,255.60$ & 7.98 & \\
\hline Hollow & 278.27 & 1.77 & \\
\hline Footslope & $1,719.68$ & 10.93 & \\
\hline Valley & 839.61 & 5.33 & \\
\hline Pit & 6.54 & 0.04 & \\
\hline
\end{tabular}

Table 03 - Area and percentage of the landform elements.

Figure 07 shows the detailed representation of the spatial distribution of the landform elements in the Southeast portion of the watershed.
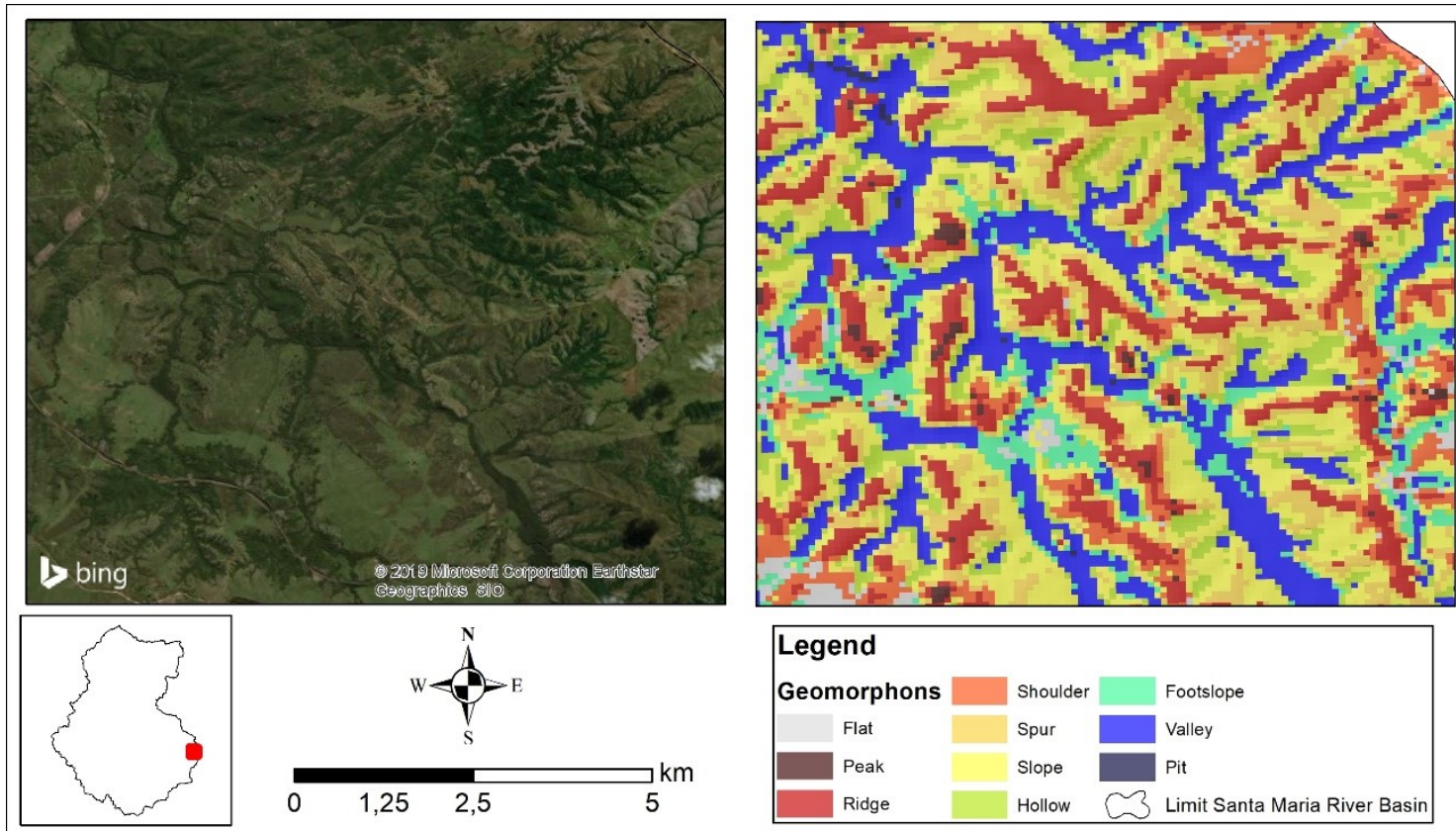

Figure 07 - Landform elements in the southeastern portion of the river basin. Source: authors

The slightly undulated hills reflect the predominance of the Flat and Footslope elements. The Slopes are large, smooth landforms and form $7.98 \%$ of occurrences. The elements defined as Shoulders occur in the resistant rocks. In the NE portion of the Santa Maria river basin, the predominant elements in the Cacequi river basin are Slopes with broad bases and elongated Ridges formed by secondary extensions (Spurs) and Shoulders. The drainage develops principally in the Valleys and is associated with the Hollows on the lower parts of the half slope, characterized by extensive linear erosion processes.

The western areas that mark the watershed of the basin are associated with the larger hills especially Valleys and Ridges. In the SE portion of the Santa Maria river basin, in the Jaguari-Taquarembó drainage basin, the predominant elements are Slopes with broad bases and narrow 
and elongated tops associated with Ridges and Spurs.

\section{ANALYSIS OF THE SLOPE FORMS}

The characteristics of the slopes that make up the relief in the Santa Maria river basin are defined in eight units, based on a declivity of $5 \%$, the profile, and plane curvature (figure 08 ). Table 4 presents the area and percentage occupied by the slope forms in the river basin.

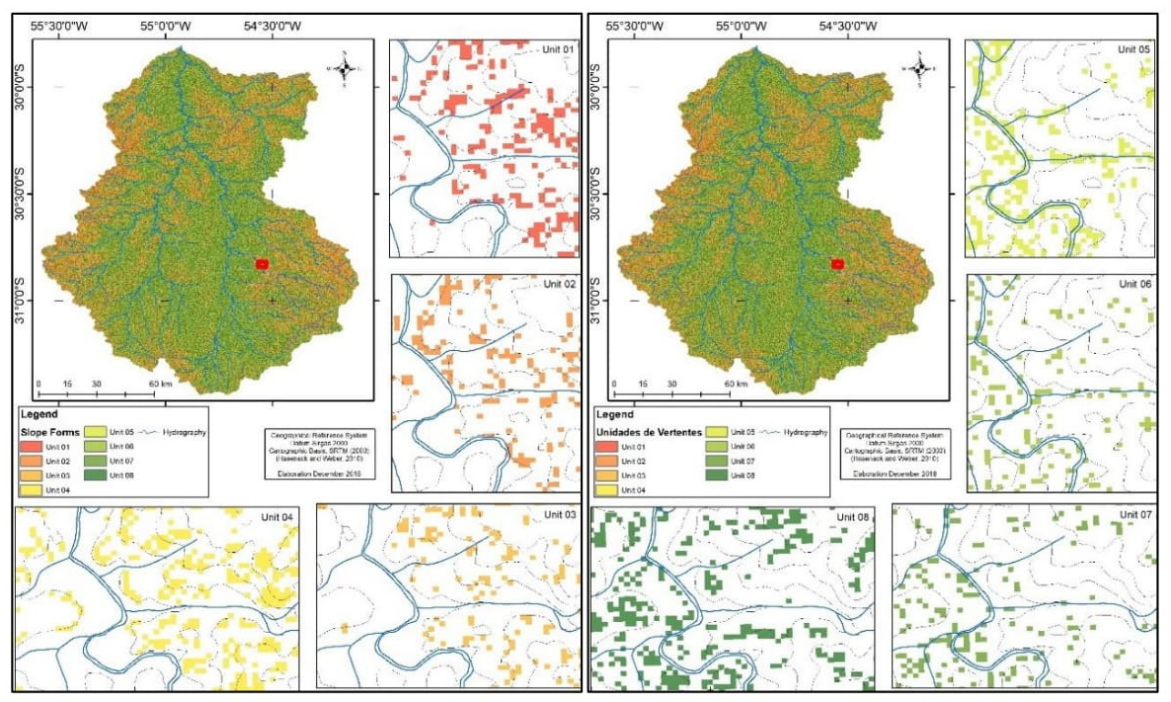

Figure 08 - Spatial distribution of slope forms in the Santa Maria river basin. Source: authors.

\begin{tabular}{l|l|l|l|r|r}
\hline Classes & Declivity & Profile & Plan & Area $\mathbf{k m}^{2}$ & Percentage \\
\hline Unit01 & $>5 \%$ & $\mathrm{Cc}$ & $\mathrm{cv}$ & $1,215.91$ & 7.72 \\
\hline Unit02 & $>5 \%$ & $\mathrm{Cc}$ & $\mathrm{dv}$ & 887.01 & 5.64 \\
\hline Unit03 & $>5 \%$ & $\mathrm{Cx}$ & $\mathrm{cv}$ & 530.39 & 3.37 \\
\hline Unit04 & $>5 \%$ & $\mathrm{Cx}$ & $\mathrm{dv}$ & $1,394.60$ & 8.86 \\
\hline Unit05 & $<5 \%$ & $\mathrm{Cc}$ & $\mathrm{cv}$ & $4,155.94$ & 26.40 \\
\hline Unit06 & $<5 \%$ & $\mathrm{Cc}$ & $\mathrm{cv}$ & $1,353.10$ & 8.60 \\
\hline Unit07 & $<5 \%$ & $\mathrm{Cx}$ & $\mathrm{dv}$ & $2,923.79$ & 18.58 \\
\hline Unit08 & $<5 \%$ & $\mathrm{Cx}$ & $\mathrm{dv}$ & $3,279.67$ & 20.84 \\
\hline
\end{tabular}

Table 04 - Area and percentage of the slope forms.

The declivity of $5 \%$ is associated the limit of the erosive processes, the curvature plane corresponds to the variation of the arching gradient in the slope's orthogonal direction and the curvature profile of is the variation rate of the arching gradient in the direction of its orientation.

Units 01, 02, 03, and 04 (FIGURE 09) have a declivity above 5\%, indicating the portions of the slopes where erosive processes become significant.

Units 01 and 02 have concave profiles, with a relatively higher runoff at the top than at the base. Unit 01 has a convergent flow and is associated with the main channel of the first and second-order drains. Unit 02 has a divergent character and is associated with the previous unit; however, it occurs in a dispersed way.

Units 03 and 04 have a convex profile where the runoff increases from the top towards the base. Unit 03, with flow concentration, is represented by semicircles depressions that occur in the basin. Significantly, Unit 04 contains the slope segments that occur in the inter-fluvial areas of the hills. 


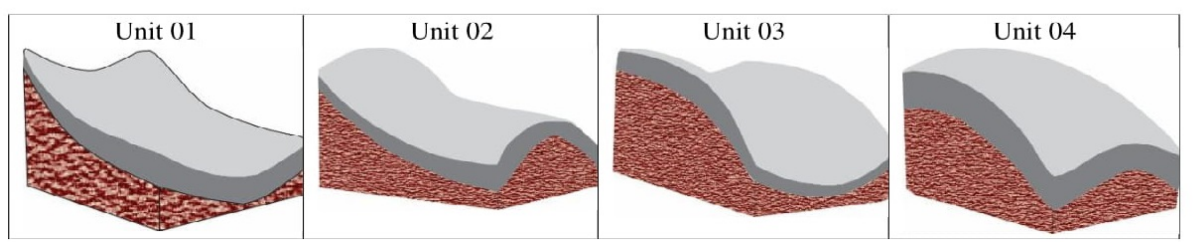

Figure 09 - Schematic drawing of units 01, 02, 03 and 04. Source: the authors, adapted from Curcio (2006).

Units $05,06,07$, and 08 (FIGURE 10) are characterized by a declivity of less than $5 \%$ so that the slopes that occur are slightly undulated hills and flat areas. Units 05 and 06 are concave in profile, the former is converging and occurs next to the superior order channels, forming open valleys with little inclination. Unit 06 is fragmented and forms portions of slopes with divergent flows.

Units 07 and 08 have convex profiles. Unit 07 is converging, whereas unit 08 , has a divergent character, forming the shapes that mark the tops of the slightly undulated hills and areas of the floodplain.

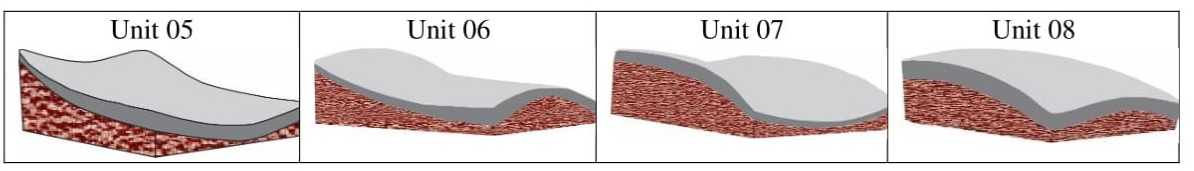

Figure 10 - Schematic drawing of units 05, 06, 07 and 08. Source: the authors, adapted from Curcio (2006).

\section{CLASSIFICATION OF LANDFORMS IN THE SANTA MARIA RIVER BASIN.}

The classification by landforms, landform elements, and slope forms is shown in figure 11.

\begin{tabular}{|l|l|l|}
\hline Forms & Elements & Slopes \\
\hline & & \\
\hline
\end{tabular}

Figure 11 - Summary of landforms classification in the catchment area. Source: authors. 
The register of the landform elements in each of the four landforms shows that: in the Flat Area landforms category there are only Flat elements; the Slightly Undulating Hills landforms occur Flat elements ( 55.71\%), Footslopes and Shoulders (16.70\% and $15.67 \%$ respectively); there is a greater distribution of landform elements in the Undulating Hills, with a predominance of Slopes, Ridges, and Valleys $(26.01 \%, 17.06 \%$, and $15.75 \%$ respectively); in the categories of Larger hills and Buttes the predominant elements are the Slopes, Spurs, and Ridges, with $23.49 \%, 22.03 \%$, and $20.79 \%$ respectively (FIGURE 12).

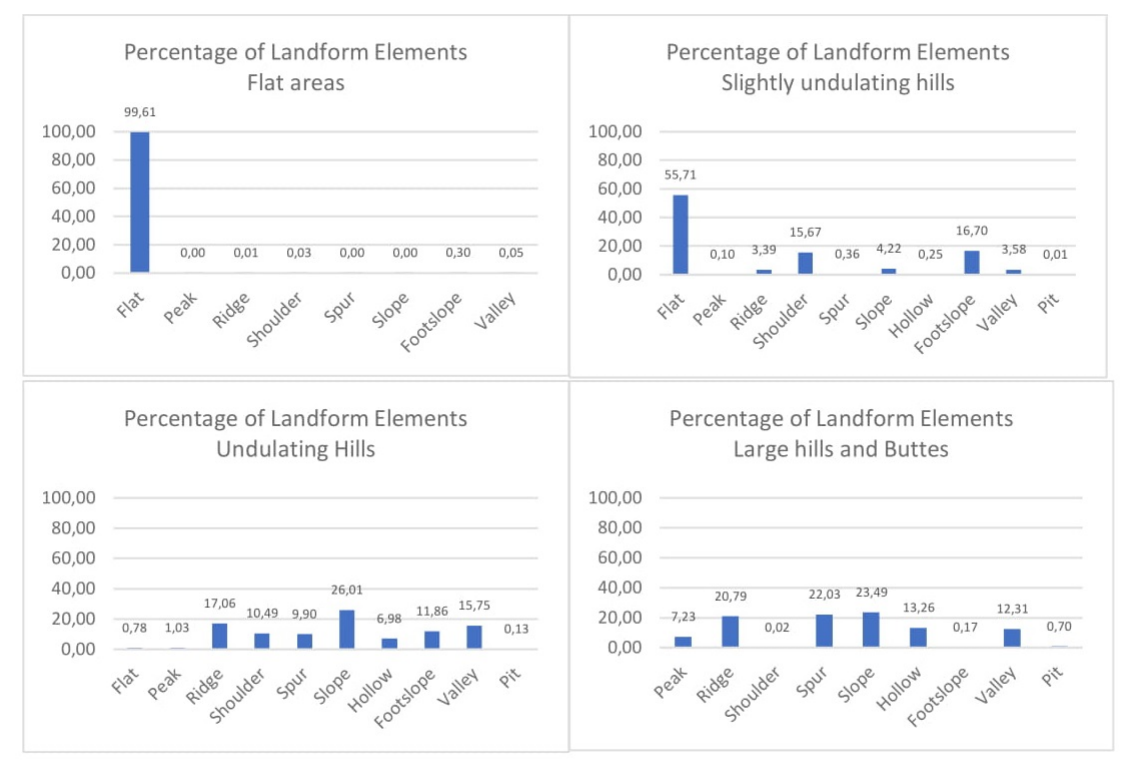

Figure 12 - Distribution of the landform elements in the relief forms.Source: authors

The form and quantity of slopes vary from one landform to another (FIGURE 13). In the Flat Areas, they are associated with drainage channels (unit 07 with $35.87 \%$ ) and undulations on floodplains (unit 05 with $35.36 \%$ ) representing the units with a convergent plane of curvature.

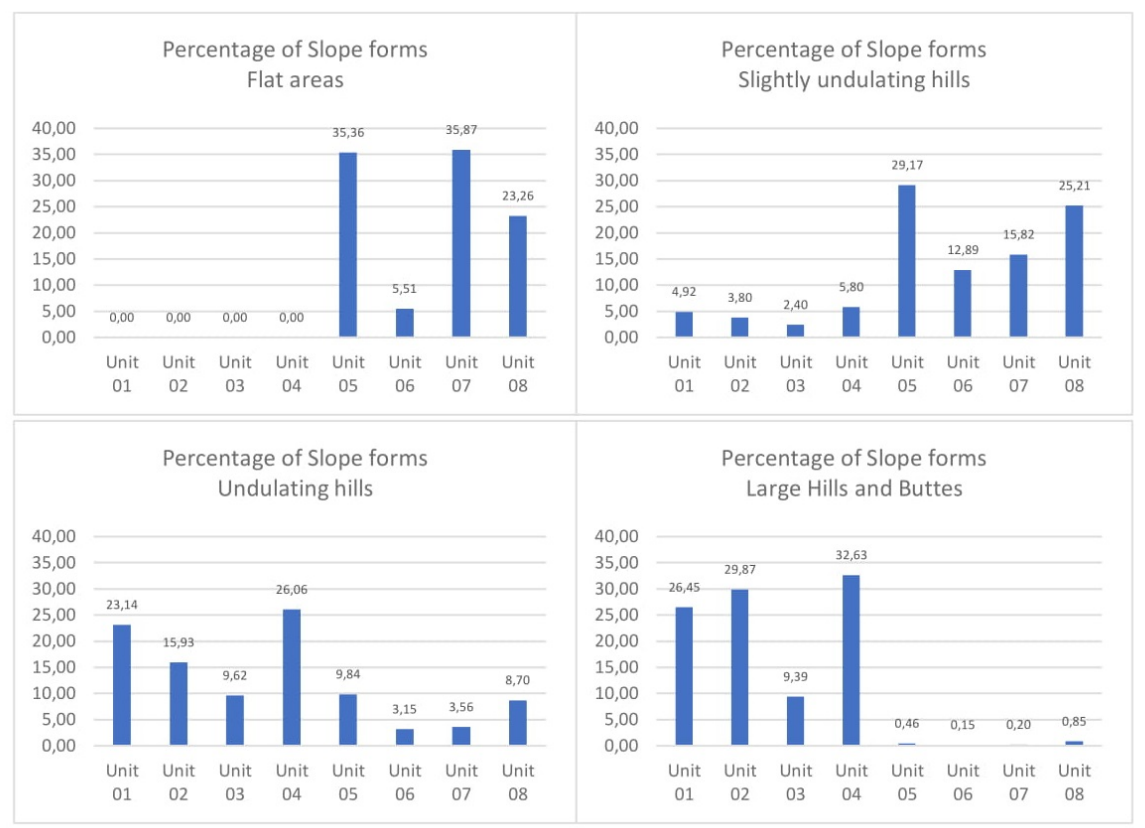

Figure 13 - Distribution of the slope forms in the different landforms .Source: authors 
In the landform category of Slightly Undulating Hills, the slopes in units 05 and 08 , with $29.17 \%$ and $25.21 \%$, respectively, have declivity lower than $5 \%$ and concave profiles with divergent planes (unit 05 ) and convex profiles with divergent planes (unit 08).

In the Undulating Hills predominance of units 04,01 , and 02 , with $26.06 \%, 23.14 \%$, and $15.93 \%$ respectively. These are the units with a declivity above $5 \%$ and convex profiles with divergent planes (unit 04), concave profile with convergent planes (unit 01), and concave profiles with divergent planes (unit 02).

The landforms characterized by Hills, Larger Hills, and Buttes was similar to the Undulating Hills, apart from an increase in the percentages in units $04(32.63 \%)$, unit $02(29.87 \%)$, and unit 01 $(26.45 \%)$.

\section{CONCLUSION}

River basin's processes are directly related to the characteristics of their constituent elements. Landforms are a fundamental component since they condition the flow of materials controlling soil moisture, soil development, and erosion processes.

Using Geographic Information Systems and representing the terrestrial surface in the form of numerical digital models, (DEM), enabled the quantification of the relief utilizing equations. The quantitative information supports the interpretation and identification of the forms of relief modeling, evidencing that process mapping and analysis can be used for both qualitative and quantitative data on landforms and landform elements.

The automated analysis of topographic height and declivity defined four landforms in the Santa Maria River basin: flat areas, slightly undulating hills; undulating hills, hills with buttes and larger hills The flat areas are characterized by level elements and the main slopes are concave and convergent, whose flow is associated with drainage channels. In the category of slightly undulated hills, there is a predominance of flat and footslope elements. The slope forms have low declivity with the concave-convergent features marking the channels and convex-divergent hilltops. In the Undulating Hills there is a greater distribution of landform elements, which are characterized by Slopes, Ridges, and Valleys elements and convex-divergent slope forms associated with the wide tops of the hills. The larger hills and buttes are strictly associated with undulating hills, in a belt with an N150E direction. The western part of the basin is defined by the preponderance of Slope, Spur, and Ridge elements with short slopes and narrow tops.

Considering that landforms are the physical substrate on which human activities are developed, the analysis herein has the potential to be used in surveying and planning work since the diversity of the relief and materials that compose the slopes exert a strong influence on land use and occupation.

\section{ACKNOWLEDGMENTS}

The authors are grateful to the Fundação de Amparo a Pesquisa do Estado do Rio Grande do Sul (FAPERGS) and the Conselho Nacional de Desenvolvimento Científico e Tecnológico (CNPq) for their financial support.

\section{REFERENCES}

BATES, R.L., JACKSON, J.A. (Eds.), Glossary of Geology. 5th edition. American Geological Institute, New York, 800 pp. 2005.

CURCIO, G. R. Relações entre geologia, geomorfologia, pedologia e fitossociologia nas planícies fluviais do Rio Iguaçu, Paraná, Brasil. 2006. 511 f. Universidade Federal do Paraná, 2006. Disponível em: . Acesso em: 13 abr. 2018.

DEMEK, J. Generalization of Geomorphological Maps. In: UGI, C. de géomorphologie appliquée (Org.). . Prog. made Geomorphol. mapping. Progrès la Cartogr. géomorphologique. Brno and Bratislava: 
[s.n.], 1967. p. 36-72.

DIKAU, R. The application of a digital relief model to landform analysis. In: Raper, J.F. (Ed.), Three Dimensional Applications in Geographical Information Systems. Taylor \& Francis, London, pp. 51-77. 1989

DIKAU, R., BRABB, E.E., MARK, R.K., PIKE, R.J. Morphometric Landform Analysis of New Mexico. Zeitschrift für Geomorphologie, Supplementband 101, 109-126. 1995.

ESRI, E. S. R. I. ArcGIS Help Documentation Archive (10.3 and earlier). . Redlands, Califórnia, EUA: [s.n.]. Disponível em: . Acesso em: 13 fev. 2018. , 2018

FACCINI, U.F. 2000. Estratigrafia do Permo-Triássico do Rio Grande do Sul: estilos

deposicionais versus Espaço de Acomodação. Porto Alegre. 300p. Doutorado.

Instituto de Geociências - Universidade Federal do Rio Grande do Sul, Brasil.

GOMES, S. M. A.; SIL VEIRA, C. T. da; SILVEIRA, R. M. P. Compartimentação Geomorfométrica de Unidades de Relevo das Cartas MI 2726-4 e MI 2820-2 - Estado do Paraná. 2016, Maringa/PR: UGB, 2016. p. 5. Disponível em: . Acesso em: 13 fev. 2018.

HAMMOND, E.H. What is a landform? Some further comments. The Professional Geographer, 17 (3), 12-13. 1965.

HASENACK, H.; WEBER, E. (org. . Base cartográfica vetorial contínua do Rio Grande do Sul - Escala 1:50.000. . Porto Alegre: UFRGS Centro de Ecologia. Disponível em: . Acesso em: 7 abr. 2015. , 2010

HORN, B. K. P. Hill shading and the reflectance map. Proceedings of the IEEE, v. 69, n. 1, p. 14-47, jan. 1981. Disponível em: .

HUGGETT, R. J. Soil landscape systems: A model of soil Genesis. Geoderma, v. 13, n. 1, p. 1-22, fev. 1975. Disponível em: . Acesso em: 25 ago. 2016.

INSTITUTO DE PESQUISAS TECNOLÓGICAS (IPT). Mapa geomorfológico do Estado de São Paulo. Escala 1:500.000. . São Paulo: IPT Publicação 1183. , 1981

IWAHASHI, J.; PIKE, R. J. Automated classifications of topography from DEMs by an unsupervised nested-means algorithm and a three-part geometric signature. Geomorphology, v. 86, n. 3-4, p. 409-440, 2007.

JASIEWICZ, J.; STEPINSKI, T. F. Geomorphons-a pattern recognition approach to classification and mapping of landforms. Geomorphology, v. 182, 2013.

KRETSCH, J. L. Shuttle radar topography mission overview. 2000, [S.1.]: Institute of Electrical and Electronics Engineers Inc., 2000. p. 276-282.

LAVINA, E.L. 1992. Geologia sedimentar e paleogeografia do Neopermiano e Eotriássico (Intervalo Kazaniano- Scitiano) da Bacia do Paraná. Porto Alegre. Instituto de Geociências, Universidade Federal do Rio Grande do Sul, Tese de Doutoradomento, 512p.

LEIGHTY, R. D. Automated IFSAR Terrain Analysis System: Final Report. U.S. Army Aviation \& Missile Command, Defense Advanced Research Projects Agency (DoD) Information Sciences Office, Arlington, VA, 59 pp. 2001.

LOBECK, A.K. Geomorphology: An Introduction to the Study of Landscapes. McGraw-Hill, New York, 731 pp. 1939.

MINATEL TINÓS, T. et al. Aplicação e avaliação de metodologia de classificação automática de padrões de formas semelhantes do relevo. Revista Brasileira de Geomorfologia, v. 15, p. 353-370, 2014.

MUÑOZ, V. A. Análise Geomorfométrica de Dados SRTM Aplicada ao Estudo das Relações Solo-Relevo. 1. ed. São José dos Campos: Dissertação (Mestrado em Sensoriamento Remoto), 2009. 
ROBAINA, L. E. D. S.; TRENTIN, R.; LAURENT, F. COMPARTIMENTAÇÃO DO ESTADO DO RIO GRANDE DO SUL, BRASIL, ATRAVÉS DO USO DE GEOMORPHONS OBTIDOS EM CLASSIFICAÇÃO TOPOGRÁFICA AUTOMATIZADA. Revista Brasileira de Geomorfologia, v. 17, n. 2, 30 jun. 2016. Disponível em: . Acesso em: 31 maio 2018.

ROBAINA, L.; TRENTIN, R.; LAURENT, F. Zoneamento em Unidades Morfológicas da Bacia do Rio Oudon, Noroeste da França, a partir de MDT em Ambiente de SIG. Geografia 0100-7912, v. 41, 2016.

ROSS, J. L. S. Geomorfologia. Ambiente e Planejamento. 1. ed. São Paulo: Contexto, 1990.

O Registro Cartográfico dos Fatos Geomórficos e a Questão da Taxonomia do Relevo. Revista do Departamento de Geografia, v. 6, p. 17-29, 1992. Disponível em: . Acesso em: 15 dez. 2018.

SENA-SOUZA; J; NEVES, G.; VASCONCELOS, V.; MARTINS, E.; JUNIOR, A. Mapeamento das Formas de Terreno por meio de Assinatura Geomorfométrica como Subsídio para a Descrição da Paisagem da Bacia Hidrográfica do Alto Rio Preto. Anais XVII Simpósio Brasileiro de Sensoriamento Remoto - SBSR, João Pessoa-PB, Brasil,25 a 29 de abril de 2015, INPE, pag. 1617-1624.

ROSSATO, M. S. Os Climas do Rio Grande do Sul: variabilidade, tendências e tipologias. Porto Alegre: UFRGS/PPGEA, 2011. [240 f.] il. Tese (Doutorado)

SCHMIDT, J.; HEWITT, A. Fuzzy Land Element Cclassification from DTMs Based on Geometry and Terrain Position. Geoderma, 2004, vol. 121. Pag. 243-256.

SHARY, P. A., SHARAYA, L.S., MITUSOV, A.V. The problem of scale-specific and scale-free approaches in geomorphometry. Geografia Fisica e Dinamica Quaternaria, 28 (1), 81-101. 2005.

SHARY, P.A. Land surface in gravity points classification by a complete system of curvatures. Mathematical Geology, 27 (3), 373-390. 1995.

SILVEIRA, C. T.; SILVEIRA, R. M. P. ÍNDICE DE POSIÇÃO TOPOGRÁFICA (IPT) PARA CLASSIFICAÇÃO GEOMORFOMÉTRICA DAS FORMAS DE RELEVO NO ESTADO DO PARANÁ - BRASIL. Raega - O Espaço Geográfico em Análise, v. 41, n. 0, p. 98, 28 ago. 2017. Disponível em: . Acesso em: 30 out. 2017.

SILVEIRA, C. T. da et al. Automated classification of landform elements in the state of paraná (Brazil) applying the proposal of the geomorphons. Revista Brasileira de Geomorfologia, v. 19, n. 1, 2018.

SILVEIRA, R. M. P.; SILVEIRA, C. T. Classificação hierárquica automatizada de formas do relevo no estado do Paraná apoiada na modelagem digital do terreno. Revista Brasileira de Geografia Física, v. 8, n. 3, p. 1509-1523, 2015. Disponível em: . Acesso em: 24 out. 2017.

SILVEIRA, R. M. P.; SILVEIRA, C. T. da. ANÁLISE DIGITAL DO RELEVO APLICADA À CARTOGRAFIA GEOMORFOLÓGICA DA PORÇÃO CENTRAL DA SERRA DO MAR PARANAENSE. Revista Brasileira de Geomorfologia, v. 17, n. 4, 15 dez. 2016. Disponível em: . Acesso em: 24 out. 2017.

SILVEIRA, R. M. P.; SILVEIRA, C. T. da; OKA-FIORI, C. Revista brasileira de geomorfologia. [S.1.]: Unia

o da Geomorfologia Brasileira, 2014. v. 15. Disponível em: . Acesso em: 13 fev. 2019.

SPEIGHT, J. G. A parametric approach to landform regions. In: Progress in Geomorphology, Special Publication, vol. 7. Institute of British Geographers, Alden \& Mowbray Ltd at the Alden Press, Oxford, pp. 213-230. 1974.

TRENTIN, R.; ROBAINA, L. E. D. S.; BARATTO, D. D. S. Análise De Elementos Do Relevo Através Do Topographic Position Index (Tpi) Da Bacia Hidrográfica Do Arroio Puitã - Oeste Do Rio Grande Do Sul/Brasil. Geography Department University of Sao Paulo, 2016.

TRENTIN, R.; ROBAINA, L. E. de S. CLASSIFICÃO DAS UNIDADES DE RELEVO ATRAVÉS DE PARÂMETROS GEOMORFOMÉTRICOS. Mercator (Fortaleza), v. 15, p. 53-66, 2016. Disponível 
em: .

TRENTIN, R.; ROBAINA, L. E. de S.; SILVEIRA, C. T. da. Revista Brasileira de Geomorfologia COMPARTIMENTAÇÃO GEOMORFOMÉTRICA DA BACIA HIDROGRÁFICA DO RIO ITÚ/RS GEOMORPHOMETRIC COMPARTMENTATION OF RIVER BASIN ITU/RS. v. 16, n. 2, 2015. Disponível em: .

U.S. GEOLOGICAL SURVEY. USGS Global Visualization Viewer. Water-use. [S.1: s.n.]. Disponível em: ., 2016

U.S. GEOLOGICAL SURVEY. LP DAAC - Release of NASADEM Data Products. Disponível em: . Acesso em: 8 abr. 2020.

VALERIANO, M. de M. Modelo Digital de Elevação com Dados SRTM Disponíveis para a América do Sul. . São José dos Campos/SP: [s.n.], 2004. Disponível em: .

VIDAL-TORRADO, P.; LEPSCH, I. F.; CASTRO, S. S. Conceitos e aplicações das relações pedologia-geomorfologia em regiões tropicais úmidas. Tópicos em Ciência do Solo. Viçosa: Sociedade Brasileira de Ciência do Solo, 2005. p. 145-192.

WEAVER, G.D. What is a landform? The Professional Geographer, 17 (1), 11-13. 1965.

ZEVENBERGEN, L. W.; THORNE, C. R. Quantitative analysis of land surface topography. Earth Surface Processes and Landforms, v. 12, n. 1, p. 47-56, 1987. Disponível em: .

ZINCK, J.A., VALENZUELA, C.R. Soil geographic database: structure and application examples. ITC Journal, 1990 (3), 270-294. 1990. 